\title{
A Political Education Model of Political Parties in Indonesia
}

\author{
Vina Salviana Darvina Soedarwo* \\ Doctor of Social and Political Sciences of University of Muhammadiyah Malang
}

\begin{abstract}
*Corresponding Author: Vina Salviana Darvina Soedarwo, Doctor of Social and Political Sciences of University of Muhammadiyah Malang
\end{abstract}

\begin{abstract}
One of the classic reasons for being a scapegoat from women's political backwardness is a matter of patriarchal culture, where, women are considered to be more suitable to take care of domestic (private) areas while men in the public sphere. This reason certainly tends to be cliched, because if we are honest, the low number of representation of women in the political space cannot be separated from the influence of the political party (political party) platform itself. The partisanship of political parties towards gender equality is still half-hearted. As an important pillar of democracy, it is time for political parties to take on the role of making the agenda of women's representation successfully. This study aims to find out the political party platform. What is the model of political education carried out in political parties? Is it based on gender sensitivity? The results of this study indicate that from the platforms of four political parties (PDIP, Golkar, Gerindra, and $P K S$ ), the missions, objectives, and gender-sensitive programs have not been explicitly stated yet. In the four political parties, there has been no specific implementation of gender sensitivity-based political education. Only a few programs are related to the field of women. From the conditions of political education d mentioned above, a model of gender sensitivity-based political education can be developed.
\end{abstract}

Keywords: Political education model, gender sensitivity, political parties

\section{INTRODUCTION}

The portray of the journey of women's involvement in the parliament context began when women were given rights to vote and compete in the general election in 1995. Historically, however, the level of the political representation of women in Indonesia was still low. According to Budi Shanti (12001), in the legislative period (Temporary Parliament) of 1950 to 1955, the women's representation was $3.8 \%$ from 236 parliament members, and 6.3\% from 272 members between 1955 and 1960, respectively (2001: 21). For 30 years, the highest percentage of women's representation was $15 \%$ in the legislative period of 1987 to 1992, while in the 1999 general election, it merely reached $9.82 \%$ from the whole number of the parliament members. Quantitatively, this shows some reduction in women's representation from the 1997 general election that gained 11.62\% [1].

In the 2004 general election, in Indonesia from the total number of women which was greater than that of men, consisting of $51 \%$ of the total voters of $141,957,895$ persons, the percentage of women becoming the members of the DPR-RI (House of Representative of the Republic of Indonesia) members was merely $11.81 \%$, while that of the DPD-RI (Regional Representative Council) was $21.09 \%$ [1]. It was also the case in the 2009 and the 2014 general elections, the number of women serving in the DPR-RI was 100 persons $(17.86 \%)$ and 97 persons (17.32\%), respectively. This phenomenon is apprehensive since the reformation in Indonesia is expected to make democracy better in terms of gender equality in various fields, including in political one. Table I represents the trip of the women's representativeness in the parliament from the results of the election of the legislative members in the reformation era.

Table1: The Comparison of the Number of the Members of the Dpr-Ri During the Post Reformation Era Based on Gender

\begin{tabular}{|r|l|l|l|l|l|l|}
\hline Period & Women & \multicolumn{1}{c|}{ M } & Men & \% & Total & \% \\
\hline $\mathbf{1 9 9 9 - 2 0 0 4}$ & 44 & 8.80 & 456 & 91.20 & 500 & 100 \\
\hline $\mathbf{2 0 0 4 - 2 0 0 9}$ & 65 & 11.82 & 485 & 88.18 & 550 & 100 \\
\hline $\mathbf{2 0 0 9 - 2 0 1 4}$ & 100 & 17.86 & 460 & 82.14 & 560 & 100 \\
\hline $\mathbf{2 0 1 4 - 2 0 1 9}$ & 97 & 17.32 & 463 & 82.68 & 560 & 100 \\
\hline
\end{tabular}


Fig1: KPU (cited from the Publication of Indonesian Statistics in 2015)

It seems that the mandate of the Law number 8 year of 2012 on the General Elections of the Members of DPR, DPD, and DPRD stating that women' representativeness of at least $30 \%$ has not been reached although women's political representativeness has been declared in the Convention on the Elimination of All Forms Discrimination Against Women and the Convention of Women's Political Rights in the United Nation Charter. One of the classical reasons serving as the scapegoat from women's political backwardness is a matter of patriarchal culture, where women are considered to be more suitable to do domestic (private) affairs, while men are more appropriate with working in public spaces. Women are thought to be identical with taking care of the kitchen, well, and mattress though this reason is cliché in nature. Frankly, the low number of women's representativeness in the public space is inseparable from the effect of the political party platform itself. The partisanship of the political party to gender equality is still half-hearted. It is time for the political party to play its role in succeeding the agendum of women representativeness. Such an agendum is crucial for promoting any policies resulting from either the legislative or executive realm which may be proportional and sensitive to gender. The matter of gender sensitivity- based political education is important to study since it may delineate how the partisanship of a political party towards women interest is, whereas the reformation has been reaching 20 years of age where the process of democracy should enter into some sensitivity to notable issues about women. What is necessary to investigate is as follows: What is the relationship between a political party platform and women candidacy for legislative members? What is the gender sensitivity-based political education model applied in a political party? The urgency of this study is what is mandated in the 1999 GBHN (Broad Outline of State Policy) that it is necessary to have an institution that can carry out any national policies to realize gender equality and justice. Even the Presidential Instruction number 9 the year of 2000 regarding Gender Mainstreaming in the National Development.

The basic idea of applying a quota system in recruiting women to able to occupy certain positions in the parliament is that they will not bear an impression that their existence in the parliament will not serve as a complement and political display. Such a quota system also assures women to be able to attain a "critical minority" of 30\%. This quota system is intended to improve women representativeness in parliament. It is a choice of which its meaning is delineated by Reyes as follows: (a) Quota system principally is to place a minimal percentage for the two roles of gender namely those of women and men to assure the existence of an equilibrium position and role between them in the political domain, especially in any decision making. (b) Quota system means giving chances by "forcing" a certain percentage to a certain group of people (in this case, women). This system does not have any powerful legal basis. Moreover, Ekmeji [2] also suggested that the main idea behind this quota system be that women are not isolated from any political life. They usually set a target or a minimal threshold for women intended to ensure that women attain a "critical minority" of 30 or 40 percent in the position of any decision making. There are some types of a quota system that may be applied through either a constitutional quota for a national parliament such as quota in law on the general election or an internal structure in a political party. Up to now, 92 counties have been applying the constitutional quota system, legislative mandate, or voluntary political party quota [3].

This quota system is greatly relevant to the condition in Indonesia, remembering that the percentage of the female population is more than $50 \%$ of the male population and female voters in Indonesia reached $57 \%$. Therefore, this quota system shows that the general election system has given an adequate significant opportunity. Then, How is about the role of a political party?

Some political parties in Indonesia have shown their commitments to provide women with a certain portion to be able to be nominated as legislative members, although it is still far from the expectation. Political parties still place female cadres in the "low" position, instead of "high" one, where this condition has resulted in some dissatisfaction among female legislative candidates, observers, or women activists.

Support from political parties is very crucial since this serves as a political machine to accommodate candidates of legislative members to the parliament. Therefore, political party management must be aware of gender equality, especially the trust of political parties to their female cadres. The importance of the political parties has been enhanced by the changes in the election system of legislative members in 1999 where the seats in parliament are not based anymore on the order, but on the most votes from each legislative candidate. This situation gives a great challenge for female 
politicians in front of their political parties or of their community and this tests the quality of female politicians.

Another opportunity is that the socio-cultural condition of the society has started to change, wherein the reformation era, the people have possessed some awareness of accepting women to play some political roles, although it is still in a transitional condition where some elements of old climates still give some colors to the society in the transition from an authoritarian to democratic style.

From the reality that has been described, it is interesting to study how the political party platforms and how the gender sensitivity-based political education model is implemented in political parties in Indonesia. In this study four political parties were chosen, namely, Demokrasi Indonesia Perjuangan Party (PDIP) and Golongan Karya Party (GOLKAR) represent pre-reformation era while Partai Gerakan Indonesia Raya (Gereindra) and Partai Keadilan Sejahtera (PKS) represent the postreformation era.

\section{LiTERATURE REVIEW}

Political education is vital since it is a process of giving political learning to cadres and the people that in general should be committed instantly and consistently by the concerned parties aimed at making the cadres and the people aware of the problems of the nation and state. Even in the article 1 no. 4 of the Law no. 2 of 2008 on Political Parties [4], it is stated that political education is the process of learning and comprehension of the rights, obligations, and responsibilities of each citizen in the life of the nation and state. As a result, political education in political parties is important in the state possessing a democratic climate like Indonesia. Political education is crucial since it will form the people's political behaviors. Conceptually, political education is a process through some stages: (a) traditional, patriotic political education, (b) institutional political education, and (c) political behavioral education.

Besides as a medium for shaping behaviors of cadres of a political party through political education, the political party also gives an opportunity to determine any women participation and representativeness. There are four factors in the existence of a political party that significantly determines the level of women representativeness in the parliament: a) Organizational structure; b) Framework; c) Ideology; and d) Women activists [5]. The four factors may always be met by the whole political parties in Indonesia, also Indonesia is still developing democracy.

In developing democracy, greater participation and higher representativeness of women in political parties are prerequisites for the realization of more meaningful democracy. Meaningful democracy is the one noticing and struggling the interest of the majority population in Indonesia, namely women. In Indonesia, however, women have just occupied around $18 \%$ of the legislative seats.

Some factors causing such low participation the women played in the political parties have been identified in Vijayakumari and Rao's research results namely men's domination in the political parties, the structure of the political cultures, and the structure of the formal politics. Political parties dominated by men possess perspectives of important national issues and women are often disappointed with the fact that their interests are frequently abandoned in their political parties. Female cadres are usually not allowed to occupy powers in structures of parties due to gender bias under male leadership [6].

In line with Vijayakumari and Rao's findings described above, factors causing a minimal number of women in elective positions are suggested by Hendrarti [7] that: (a) The arena of the relative contestation is limiter from the side of the winners since the arena merely gives limited space to the contestants. This causes the opportunities the contestants get to be smaller and narrower, especially for women to be elected to occupy elective positions. (b) A minimal model of women in politics makes the voters have very limited knowledge of women who succeed in political positions. This implies that the voters tend not to consider the importance of women in holding elective positions in local head elections. This condition is worsened by the fact that the people have not been genderfriendly, where they never give any attention to the urgency of the presence of women in elective positions. (c) Women who become candidates in local head elections indeed do not have any electability, where their existence is more encouraged by external factors based on the coercion where the quota of women in political parties should be 30\%. (d) Low experiences among women in political life are not compensated by some aids and encouragements from political parties to promote 
female candidates in local head elections.

Suryadi's findings also reinforce the reality that a minimal number of female politicians occupying political positions are caused by some discriminations that tend to exploit the proportion of women in the structure of bureaucracy and the other accesses to development. The paradigm adopted in the structure of bureaucracy in the people, the nation and the state is still complementary in nature because of a perspective that the main task that should be conducted by women is to handle domestic domain [8].

In this reformation era, some development of women's participation in political positions is found, especially in certain areas such as Surabaya although a long journey should be taken. Tuasun's [9] research results show that the candidacy of female legislative members should pass through three states: self-selection, party selection, and election. Female legislative candidates who are courageous to involve themselves in any political domain should have enough capability in expressing their own political spirits well. Any ambition and capacity possessed by each women politician who takes part in the candidacy in legislative position will, at last, be able to make them decide to run for office. At the stage of candidacy, women politicians should try to lobby the officials of political parties dominated by men. Any capability and various capitals including a close relationship with any officials of political parties should be made use of by each female candidate in the process of political lobbying.

It seems that the majority of female politicians in Indonesia merely participate at local level namely DPRD (local house of representative), where the percentage of their participation at the central DPR has not reached $30 \%$ yet. Rai et al [10] also suggest that factors that support women to participate in political parties are as follows: (a) Women tend to be comfortable to take part in the local political level which is not far from their residence; (b) At the "local" level, they have a closer relationship with the needs of their constituents than when they play at "national" level; (c) Due to a high illiteracy level at local area, female politicians are far easier to handle this problem than when they should solve a "high level of any political problems."

An existentialist view of Simone de Beauvoir can be used to explain the reality of subordination female politicians. As Beauvoir said that "women are the second sex or others". Women are called 'other' because of sex. Women are different and are also distinguished from men because of their role, function, strength in society, and this distinction is based on sex. The community has set a grade of women are "the second sex" [11]. Beauvoir stated that although biological and psychological facts about women can be true, how we judge this fact is dependent on us as social beings [12]. For Beauvoir, biology is not enough to answer the question that confronts why women are 'other' [13]. So, the second sex is not psychological category related to sexual behavior, nor is it in the sociological category that says social functional roles; not also in the anthropological category which refers to a personality that is specific to men. However, "the second sex" is in everyday ontological and transcendental category at the same time [11]. Likewise, with women who play a role in political space, she will still be the second sex.

\section{MeThodologY}

An interpretive approach with descriptive qualitative research type was employed in this present research. Interpretivism is formed by an idea grew from the hermeneutic tradition from Germany [14]. This interpretive approach emphasizes that knowledge is not something we construct using any methods which are far away from what we will know. This is confirmed by some confidence shown by Heidegger that no way is found by any subject/observer to separate her/himself from any object s/he observes. In this matter, any search for knowledge is conditioned by cultures, contexts, and histories. As a result, the instrument in this present research was the researchers herself and she recorded all data presented by the subjects as the readers of a "text" or "text analog" (event). According to Geertz, the concept of "text analog" is used as a procedure used in interpreting a culture. It is known from previous studies that the phenomenon of gender bias has been mostly caused by social construction and culture. Therefore, it is appropriate to use this approach to study gender sensitivity in political education. The subjects of this present research were the main managers, the chairs, the heads of division of women and cadres from the four parties.

The technique of data collection commonly used in qualitative research was to make direct (naturalistic) observations to each location based on the following guidelines: (1) The condition of 
political parties dealing with the facility of political education internally provided by the political parties; (2) The process of the political education internally held the political parties and the preparation of the election of legislative members. (3) The activities are done by the cadres of PDIP, Gerindra, and PKS in preparing their missions (containing issues of gender or not) in the 2019 legislative member election. Moreover, in-depth interviews were conducted to obtain the data on the platforms of political parties and the political education models based on gender sensitivity. A Focus Group Discussion was held because of philosophical reasons, meaning that the FGD could provide information from various perspectives so that it might enrich the findings from the documentary research results. The data were analyzed with the following stages: data reduction, data display, and verification or conclusion drawing [15] The stage of data reduction mean simplifying, abstracting, and transforming "raw" data collected from written notes in the fields. Data reduction occurred continuously during the research, even starting before the researcher decided the conceptual framework of the research area, research problems, and approach to data collection chosen in the research. Data reduction continually proceeded after the field study.

\section{RESULTS AND DISCUSSION}

Based on this research, it was revealed that each political party possessed relatively different platforms. The history of the establishment of PDIP began from the construction of Partai Demokrasi Indonesian (Indonesian Democratic Party) in 1973, where it is a party produced from the fusion of some political parties among others PNI (Indonesian National Party), MURBA ("National Communist" Political Party), IPKI (League of Upholders of Indonesian Independence), and two religious parties, Parkindo (Indonesian Christian Party) and Partai Katolik (Catholic Party). PDIP as the medium for struggle and political power of the people as stated in the Preamble of the 1945 Constitution in line with the spirit and passion of the party born on June 1, 1945. In its realization, PDIP has a national identity, democracy, and social justice with democratic, independent, tenacious, and open characters which are a whole the basis for developing the nation and national characters and motivating power and struggling the people's aspiration to become a state policy. PDIP must defend and embody the state ideals, to practice Pancasila (Five basic Principles), and to serve as the way of life in the nation and the state and to prepare the national cadres. Hence, it is through political power and strength that PDIP is determined to actualize the life of the nation which shall be free, united, sovereign, just and prosperous under the Unitary State of the Republic of Indonesia.

PDI-P is a party which has an aim to create a just and prosperous life. Therefore, its platform to emphasize the democratic principle and carry out Pancasila with full devotion to prepare the cadres of the nation.

Golkar Party struggles to realize a New Indonesia with progressive, modern, unitary, peaceful, just and prosperous characters and with religious, and cautious people who give prominence on human rights and love of the country. Democratic and just society means that a civil social order which is independent, open, egalitarian, aware of law and environment will be created. Moreover, a societymastering science and technology, possessing high work ethos and spirits and also discipline will also be realized. Golkar Party struggles to uphold, practice, and maintain Pancasila as the foundation and ideology of the nation in order to strengthen the Unitary State of Republic of Indonesia and realize the ideals of the proclamation through the implementation of the national development in all fields to create a democratic society, uphold the law supremacy, actualize the welfare of the people and human rights. Consequently, Golkar Party has a platform standing on the foundation of the Unitary State of the Republic of Indonesia based on Pancasila and 1945 Constitution. As a consequence from this platform, Golkar Party adopts a national insight: Indonesia is one and united.

Gerindra Party is a political party which is able to create the welfare of the people and social justice and also the political order of the state based on nationalism values and religiousness under the Unitary State of Republic of Indonesia with the foundation of Pancasila and 1945 Constitution. Moreover, this party also tries the followings: to create a country with sovereignty in the field of politics, personality in the field of culture and a country with full autonomy in the field of economy, to maintain sovereign and upright of the Unitary State of Republic of Indonesia on the basis of Pancasila and 1945 Constitution determined on August 18, 1945, to encourage the national development with the emphasis on the construction of the people's economy, sustainable economy growth, and the development results equitable for all the people by always paying attention of the 
self-help, to create a social order and the community politics conducive to the realization of the people's sovereignty and welfare, to uphold the law supremacy by prioritizing the presumption of the innocence and equal rights before the law regardless of the race, religion and/or group backgrounds, and to seize power constitutionally through general elections of legislative members, president and local heads in order to create layers of strong and clean national leaderships in each level of government.

PKS with the basis of Islam religion has an economic platform as follows: the wheel of the development of the economy moved by the corporate commercial community, equitable distribution of sustainable development, economic growth with high-added value, and gaining a just, welfare, and dignified society. Its political platform gives an emphasis on good governance, healthy democracy, an upholding rule of law, strong defense and security with clean, concerned, and professional human resources. All of these are based on a specific vision of this Party: PKS is a party which is influential in either the political power, participation, or opinion to create a civil Indonesia society.

The political education model based on gender sensitivity is not given a specific name in the four political parties, but each has its own model. The political education conducted by PDIP is by holding a political school attended by the figures in the political parties presenting the following materials: the socialization of 4 pillars: Pancasila, the Unitary State of Republic of Indonesia, 1945 Constitution and Bhineka Tunggal Ika (Unity and Diversity). But no specific thing could be found out in the political education related to the women's interests namely the equality between women and men, but the reinforcement of women's empowerment could be identified namely the cooperation in the establishment of women empowerment and SBW (Koperasi Setia Budi Wanita) programs.

The four political parties stated that women involved in politics have satisfied the quota, especially in the candidacy of legislative members since it has also been regulated in the Law. However, up to now in political education with the basis of gender sensitivity in political parties is still inadequate. The four parties suggested that they should make some policies of and some corrections on gender empowerment programs. Gender is considered as issues of women, and political education special for women has been inexistent yet. Normatively, for instance, the team members of a selection of the nomination of the candidates for legislative members still posed problems since many of the team members had fully not understood the problems of gender and political education for women had not been established yet.

For PDIP, a specific political education based on gender sensitivity has not existed, but some programs on empowerment for women have been implemented by its cadres. In Golkar Party, any program related to gender sensitivity is dependent on the policy from the central management, since in this party itself women are still considered as a compliment, and no structured programs based on gender sensitivity have not been formally launched. Therefore, any programs dealing with women are contingent on each branch in local management. Gerindra party had not possessed political education based on gender sensitivity, many problems still arise in the community, therefore this party should be able to find solutions for the problems. For this party, it is the real political education for its cadres.

For PKS, the issue of gender which was mostly discussed and became its program is protection for women and children, especially those dealing with bullying cases, immoral acts on children and women, and coercion for early marriage. But no political education which is special for gender sensitivity has been established since the existing programs have been emphasized on the building of the family and women tenacity.

From the reality, it can be stated that the paradigm of the roles of women in the life of the state and the nation is still complemented in nature since a perspective that the main duty of women in the domestic domain still exists in the society.

\section{CONCLUSIONS}

From the findings above, it can be concluded that the four relatively great political parties in Indonesia have not possessed a political education model based on gender sensitivity. They merely have got some programs which are related to the empowerment of women but the programs are still incidental and casuistic in nature. No political education based on gender sensitivity is one of the factors contributing to the understanding of gender equality and the importance of any knowledge on some development programs giving a priority to the women's interest. The inexistent political 
education based on gender sensitivity is also influenced by the ideology and the platform of a political party which does not touch upon women's interest or issues of women. Women's interests are ignored; women interests are dominated; women remain positioned as others. This is in accordance with what Beauvoir said that women as the second sex are in everyday ontological and transcendental category at the same time.

It is recommended that any political party in Indonesia have a platform that pays attention to women and may solve any problems on gender equality. This automatically gives birth to any programs brought about by either male or female cadres into the platforms of their political platforms that that regard the women's interest in the form of political education based on gender sensitivity. It is an effort to improve the representativeness of women in political parties quantitatively and qualitatively.

\section{REFERENCES}

[1] CETRO, "Data dan FaktaKeterwakilanPerempuan Indonesia di PartaiPolitik dan Lembaga Legislatif 1999-2001" (2002).

[2] ArdaArsenianEkmekji, (The Implementation of a Women's Quota System in Lebanese Legislation. Jurnal Al Raida .23(111-112). Fall/Winter 2005-2006, 57, (2006).

[3] Melanie Reyes, et. al., The Quota System: Women's Boon or Bane? The Centre for Legislative Development. 1 (3), (2000).

[4] The Law Number 2 Year 2008about Political Party, from www.dpr.go.id/dokjdih/document/uu/UU_ 2008_2

[5] Sri Wahyuni, and R. HedwigisEsti, "PandanganPubliktentang Keputusan PerempuandalamKancahPolitik di Indonesia" dalam GENDER AND POLITICS. Yogyakarta: Tiara Wacana, (2009).

[6] R Vijayakumariand Gangadhara.K. Rao, "Women's Political Participation in India" Global Journal for Research Analysis. 3 (8). ISSN No 2277-8160. 1, (2014).

[7] Budi WD.Hendrarti, "PerempuandalamKonteksPolitik: RepresentasiDeskriptifPerempuan pada Pileg 2014 dan Pilkada 2015”. JurnalIlmuPolitik 22 (1). ISSN: 0854-6029. Surabaya: FakultasIlmuSosial dan IlmuPolitik. UniversitasAirlangga, 87, (2017).

[8] Suryadi, “PartisipasiPolitikPerempuan Indonesia dalamRelasiGender”. JURNAL ORASI. 6(6). Department of Moslem Community Development, 8,(2015).

[9] Clarissa GheaTuasuun, "KandidasiPerempuanCaleg di Kota Surabaya dalamPemilihanLegislatif 2014”, JurnalPolitik Muda. 4 (1). Surabaya: Universitas Airlangga, 35.(2015).

[10] Shirin M Rai, FarzanaBari,NazmunessaMahtab, and BidyutMohanty, "Gender Quotas and The Politics of Empowerment-A comparative studies” in Women, Quotas, and Politics (edited by DrudeDahlerup). London-New York: Routledge Taylor \& Francis Group, 222,(2007).

[11] Armada Riyanto, C.M,Aku dan Liyan. Kata Filsafat dan Sayap. Malang: WidyaSasana Publication.(2011).

[12] Rosemarie PutnamTong,Feminist Thought. translated by Aquarini Priyatna Prabasmoro. Yogyakarta: Jalasutra. (2010).

[13] Simone deBeauvoir, The Second Sex. Harmonsworth: Penguin Books, Ltd, (1974).

[14] Norman KDenzin and Yvonna S.Lincoln, Handbook of Qualitative Research. Third edition translated by Dariyatno et al. London: Sage Publicatio, (2009).

Citation: Vina Salviana Darvina Soedarwo. "A Political Education Model of Political Parties in Indonesia". International Journal of Humanities Social Sciences and Education (IJHSSE), vol. 6, no.9, 2019, pp. 134-140. doi: http://dx. doi.org/10.20431/2349-0381.0609015.

Copyright: () 2019 Authors. This is an open-access article distributed under the terms of the Creative Commons Attribution License, which permits unrestricted use, distribution, and reproduction in any medium, provided the original author and source are credited. 